\title{
Electricity Generation and Energy Cost Estimation of Large-Scale Wind Turbines in Jarandagh, Iran
}

\author{
Kasra Mohammadi, ${ }^{1}$ Ali Mostafaeipour, ${ }^{2}$ Yagob Dinpashoh, ${ }^{3}$ and Nima Pouya ${ }^{4}$ \\ ${ }^{1}$ Faculty of Mechanical Engineering, University of Kashan, Kashan, Iran \\ ${ }^{2}$ Industrial Engineering Department, University of Yazd, Yazd, Iran \\ ${ }^{3}$ Department of Water Engineering, University of Tabriz, Tabriz, Iran \\ ${ }^{4}$ Electrical Engineering Department, Islamic Azad University, South Tehran Branch, Tehran, Iran
}

Correspondence should be addressed to Ali Mostafaeipour; mostafaei@yazd.ac.ir

Received 12 February 2014; Revised 30 September 2014; Accepted 8 October 2014; Published 30 October 2014

Academic Editor: S. Venkata Mohan

Copyright (C) 2014 Kasra Mohammadi et al. This is an open access article distributed under the Creative Commons Attribution License, which permits unrestricted use, distribution, and reproduction in any medium, provided the original work is properly cited.

Currently, wind energy utilization is being continuously growing so that it is regarded as a large contender of conventional fossil fuels. This study aimed at evaluating the feasibility of electricity generation using wind energy in Jarandagh situated in Qazvin Province in north-west part of Iran. The potential of wind energy in Jarandagh was investigated by analyzing the measured wind speed data between 2008 and 2009 at $40 \mathrm{~m}$ height. The electricity production and economic evaluation of four large-scale wind turbine models for operation at $70 \mathrm{~m}$ height were examined. The results showed that Jarandagh enjoys excellent potential for wind energy exploitation in 8 months of the year. The monthly wind power at $70 \mathrm{~m}$ height was in the range of $450.28-1661.62 \mathrm{~W} / \mathrm{m}^{2}$, and also the annual wind power was $754.40 \mathrm{~W} / \mathrm{m}^{2}$. The highest capacity factor was obtained using Suzlon S66/1.25 MW turbine model, while, in terms of electricity generation, Repower MM82/2.05 MW model showed the best performance with total annual energy output of $5705 \mathrm{MWh}$. The energy cost estimation results convincingly demonstrated that investing on wind farm construction using all nominated turbines is economically feasible and, among all turbines, Suzlon S66/1.25 MW model with energy cost of $0.0357 \$ / \mathrm{kWh}$ is a better option.

\section{Introduction}

Depletion of fossil fuel, negative effects of $\mathrm{CO}_{2}$ emission, and high price of crude oil are major concerns which influence the motivation and adoption of the renewable energies like wind, solar, geothermal, and so on. Among all renewable energy sources, wind energy, as an abundant source of energy, has the highest annual growing rate of about 30\% [1]. The aforementioned problems during the recent year have forced many scientists across the globe to pay more attention to clean energy sources like wind which is environmentally friendly and renewable [2]. It is worthwhile to mention that the economic growth and environmental pressure should be decoupled, as evidenced by international agreements on environmental policy such as the Kyoto Protocol for reducing greenhouse gas emissions [3].

The government plans to install more wind stations in Iran and, therefore, further regions should be explored. Based on Iranian Renewable Energy Organization (SUNA) data, some recent studies indicated that Jarandagh is one of the promising locations for wind power generation [4]. Exploitation of the wind power potential is significant and profitable for the regions, particularly for reducing carbon emission. Nevertheless, reliable data is of great importance for the purpose of wind resource assessment within large areas; also they provide enough information to estimate the economic viability of wind farm projects [5]. The global economic potential and technical issues of onshore wind energy were investigated by Hoogwijk et al. [6]. They illustrated costsupply curves of wind electricity for economic potential. They found that the regionally highest technical potential of onshore wind energy belonged to USA. However, lowest potentials were found for South East Asia, Southern and Western Africa, and Japan.

Many studies related to wind energy potential and assessment have been performed in various locations around 
the world. Abbes and Belhadj [7] estimated the wind resources and also wind park design in El-Kef region, Tunisia. They investigated the characteristic of wind speed using Weibull distribution function and estimated the capacity factors for different wind turbine configurations. They performed economic evaluation to examine the feasibility of their project. Mohammadi and Mostafaeipour [8] utilized different methods for comprehensive study of wind turbine utilization in Zarrineh, Iran. They used hourly, monthly, seasonal, and yearly wind data analysis. It was concluded that the location was marginal for harnessing wind energy. Also, the standard deviation and power density method were performed to determine best method for evaluation of wind power. Akpinar [9] evaluated the wind energy potential for coastal locations along the north eastern coasts of Turkey. They illustrated that the monthly mean wind speed in the region varied between $1.53 \mathrm{~m} / \mathrm{s}$ and $4.06 \mathrm{~m} / \mathrm{s}$. Also, they found that the maximum annual mean wind power density and wind energy density were $59.96 \mathrm{~W} / \mathrm{m}^{2}$ and $525.25 \mathrm{kWh} / \mathrm{m}^{2}$, respectively. Keyhani et al. [10] studied assessment of wind energy potential as a power generation source in the capital of Iran, Tehran. Long term measured wind speed data at $10 \mathrm{~m}$ height was used for this study. They calculated the annual average wind power densities which were between 74.00 and $122.48 \mathrm{~W} / \mathrm{m}^{2}$. They concluded that the wind energy potential for Tehran was suitable only for battery charging and water pumping. Islam et al. [11] investigated the assessment of wind energy potential at Kudat and Labuan, Malaysia, using Weibull distribution function. They used $10 \mathrm{~m}$ height measured wind speed data and found that highest monthly mean wind speeds were $4.8 \mathrm{~m} / \mathrm{s}$ and $4.3 \mathrm{~m} / \mathrm{s}$ at Kudat and Labuan, respectively. Also, they showed that the maximum wind power densities of Kudat and Labuan were $67.40 \mathrm{~W} / \mathrm{m}^{2}$ and $50.81 \mathrm{~W} / \mathrm{m}^{2}$, respectively. They concluded that the two locations were suitable only for small-scale wind energy applications.

Mirhosseini et al. [12] studied the potential of wind power generation for five cities in Semnan province in Iran. Mostafaeipour and Abarghooei [13] performed analysis of the wind speed data for six stations in Manjil area in north of Iran. Saeidi et al. [14] analyzed the wind potential and wind power of four locations in two provinces of North and South Khorasan in Iran. Mostafaeipour et al. [15] studied the wind energy potential of Binalood located in north-east of Iran. Mohammadi and Mostafaeipour [16] appraised the economic viability of installing 6 different wind turbines models in Aligoodarz situated in west part of Iran. Mostafaeipour et al. [17] examined the wind energy potential and economic evaluation of small wind turbines for city of Zahedan in south-east of Iran.

The aim of this study is to perform economic evaluation of installing wind turbines in Jarandagh located in Iran. This paper illustrates research work involved in estimating the electricity generation and energy cost of wind turbines. For performance evaluation of the wind turbines and finding the amount of energy that could be harnessed from wind turbines in Jarandagh area, four large-scale wind turbines (Suzlon S66/1.25 MW, HewindHW77/1500 KW, Gamesa G80/2000 KW, and Repower MM82/2.05 MW) with different rated powers are nominated.
The next section offers an overview of geographic description of the region. In Section 3, the methodology is discussed. The review of wind data analysis is presented in Section 4. Performance assessment of nominated wind turbines is brought forward in Section 5. Energy cost estimation is done in Section 6, and finally concluding remarks are presented in Section 7.

\section{Geographic Description}

Qazvin Province with an area of $15,821 \mathrm{~km}^{2}$ is located in the north-west part of Iran between $35^{\circ} 37^{\prime} \mathrm{N}$ and $36^{\circ} 45^{\prime} \mathrm{N}$ and also between $48^{\circ} 45^{\prime} \mathrm{E}$ and $50^{\circ} 50^{\prime} \mathrm{E}$. This province with only $1 \%$ of the total country area is involved in 5 percent of Iran's economy and production. Based on 2010 survey, the total population of Qazvin Province was 572,916. Qazvin Province consists of six counties, namely, Takestan, Abyek, Boin-Zahra, Avaj and Alborz, and city of Qazvin the center of the province. Also the province has 1543 villages. Jarandagh is a small village in suburb of Takestan located at $36^{\circ} 11^{\prime} \mathrm{N}$ and $49^{\circ} 48^{\prime} \mathrm{E}$ with total population of 449 [18]. Figure 1 shows the location of Qazvin Province as well as all of its six counties including Jarandagh.

The data used for this study include measured wind speed over period of two years from January 2008 to December 2009 in the time interval of $10 \mathrm{~min}$ at $40 \mathrm{~m}$ height [4]. The data was recorded at the meteorological mast installed by renewable energies organization of Iran (SUNA). For the purpose of wind speed data preparing, the ten-minute recorded data were averaged to drive hourly values. Then the hourly values were used to obtain daily, monthly, and yearly values. Finally, the obtained data were averaged over the period of two years and calculation procedure was done based on these averaged values.

\section{Methodology}

Knowledge of the wind speed frequency distribution plays a substantial role in order to estimate the potential of wind in any location. Various probability density functions exist to fit and describe the wind speed frequency over a period of time. In this study, the Weibull distribution function is used because of its simplicity and high accuracy for wind data analysis. In fact, Weibull distribution function is widely employed and adopted as an alternative method to evaluate wind energy potential and wind turbine energy output.

3.1. Weibull Distribution Function. The probability density function of Weibull distribution can be estimated as $[23,24]$

$$
f_{w}(v)=\frac{k}{c}\left(\frac{v}{c}\right)^{k-1} \exp \left(-\left(\frac{v}{c}\right)^{k}\right),
$$

where $f_{w}(v)$ is the wind speed probability for speed $v, k$ is shape parameter (dimensionless), and $c$ is scale parameter $(\mathrm{m} / \mathrm{s}) . k$ and $c$ are determined using standard deviation method as follows $[23,24]$ :

$$
\begin{aligned}
& k=\left(\frac{\sigma}{\bar{v}}\right)^{-1.086}, \quad 1 \leq k \leq 10, \\
& c=\frac{\bar{v}}{\Gamma(1+1 / k)},
\end{aligned}
$$




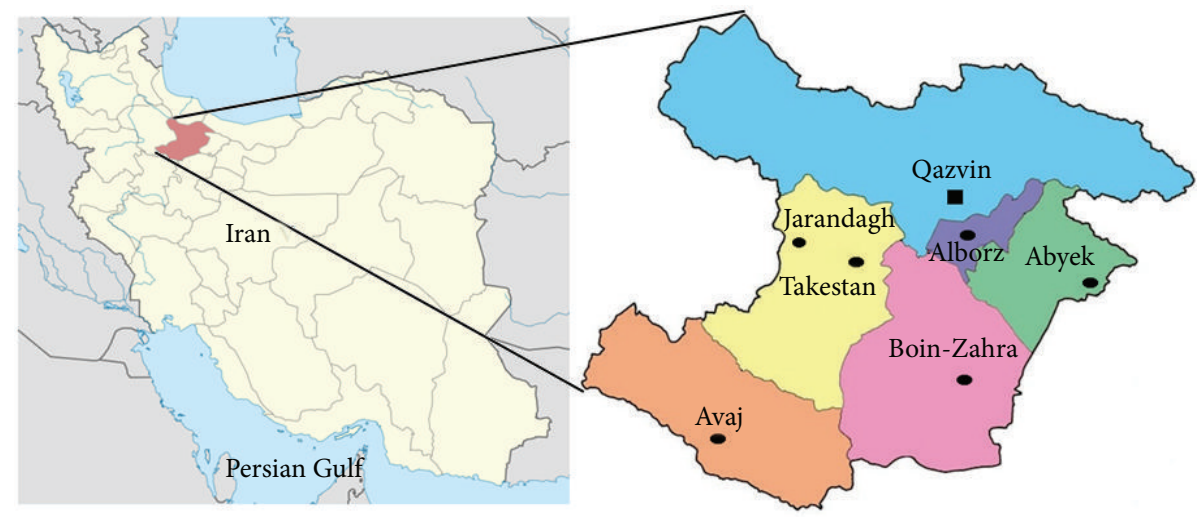

FIgURE 1: Location of Jarandagh and major counties of Qazvin Province on the Iranian map.

where $\bar{v}$ and $\sigma$ are mean wind speed and standard deviation. Also $\Gamma(x)$ is the gamma function.

The best way to judge the wind potential of a location is evaluation of the wind power density. The wind power density using Weibull probability density function can be calculated as $[25]$

$$
\frac{P}{A}=\frac{1}{2} \rho \int_{0}^{\infty} v^{3} f_{w}(v) d v=\frac{1}{2} \rho c^{3} \Gamma\left(1+\frac{3}{k}\right),
$$

where $\rho$ is the air density.

3.2. Extrapolation of Wind Data with Height. The wind speed data measured at height of $40 \mathrm{~m}$ are used in this study. Generally, wind blows slowly at lower heights. Hence, it is desirable to estimate the wind data as well as the performance of the turbines at higher hub heights. The Weibull probability density function is used to obtain the extrapolated values of wind speed at higher heights. The shape parameter $k_{h}$ and scale parameter $c_{h}$ at desired height $h$ are related to the shape parameter $k_{o}$ and scale parameter $c_{o}$ at measurement height $h_{o}$ as follows [26]:

$$
\begin{gathered}
k_{h}=\frac{k_{o}\left[1-0.088 \ln \left(h_{o} / 10\right)\right]}{[1-0.088 \ln (h / 10)]}, \\
c_{h}=c_{o}\left(\frac{h}{h_{o}}\right)^{n},
\end{gathered}
$$

where $n$ is the power law exponent (coefficient) and is defined by [26]

$$
n=\frac{\left[0.37-0.088 \ln \left(c_{o}\right)\right]}{[1-0.088 \ln (h / 10)]}
$$

\subsection{Energy Generated by Wind Turbine and Capacity Factor.} One of the key parameters that influence the performance of a wind turbine is the power response to different wind speeds usually specified by the power curve of the turbine. In fact, each wind turbine has a particular power curve. The typical power curve of a sample wind turbine is shown in Figure 2.

According to Figure 2, two major performance regions exist which can generate energy, named performance region 1

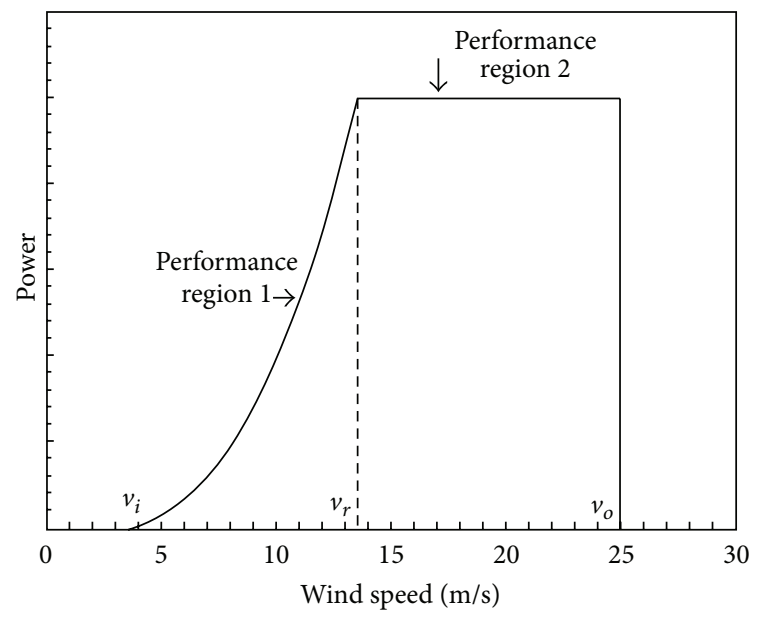

FIGURE 2: Typical power curve of a sample pitch controlled wind turbine.

and performance region 2. For these performance regions, the power curve may be approximate with the following equations [27]:

$$
\begin{aligned}
& P(v)=P_{r}\left(\frac{v^{n}-v_{i}^{n}}{v_{r}^{n}-v_{i}^{n}}\right), \quad v_{i} \leq v \leq v_{r}, \\
& P(v)=P_{r}, \quad v_{r} \leq v \leq v_{o},
\end{aligned}
$$

where $v_{i}, v_{r}, v_{o}$, and $P_{r}$ are cut-in speed, rated speed, cutout speed, and rated power, respectively. $n$ is the power-speed proportionality. Here, the ideal power-speed proportionality is assumed to be 3. The output generated energy by wind turbines in the time period of $T$ using Weibull distribution function can be expressed as follows [27]:

$$
E_{\text {out }}=T \int_{v_{i}}^{v_{o}} P(v) f_{w}(v) d v
$$

The total produced energy is the summation of produced energy in region 1 and region 2. By substituting (6a) and (6b) in (7), after some mathematical manipulation, the produced 


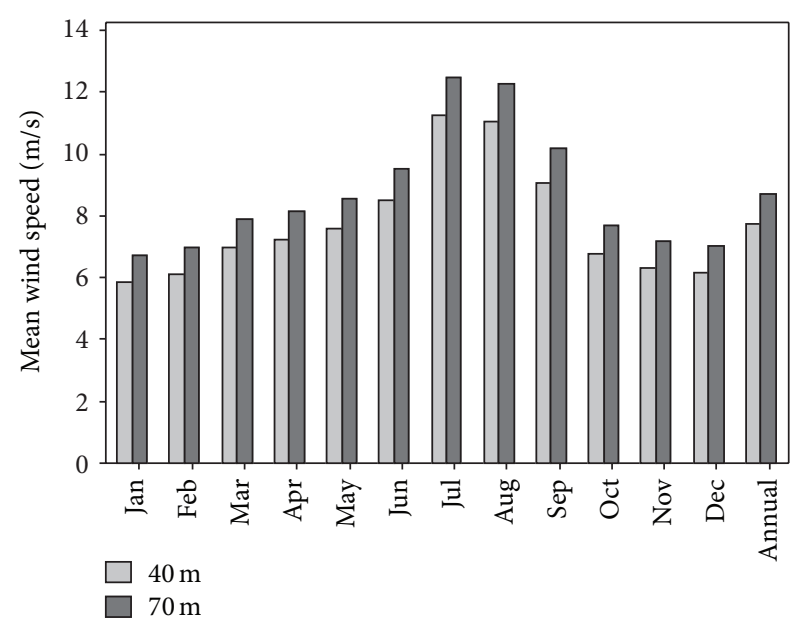

FIGURE 3: Monthly and annual mean wind speed (m/s) at 40 and 70 heights.

energy in regions 1 and 2, can be estimated by the following relations:

$$
\begin{aligned}
E_{\text {out }, 1}= & \frac{P_{r} T c^{3}}{\left(v_{r}^{3}-v_{i}^{3}\right)} \int_{x_{i}}^{x_{r}} x^{3 / k} e^{-x} d x \\
& -\frac{P_{r} T v_{i}^{3}}{\left(v_{r}^{3}-v_{i}^{3}\right)}\left(e^{-x_{i}}-e^{-x_{r}}\right), \\
E_{\text {out }, 2}= & P_{r} T\left(e^{-x_{r}}-e^{-x_{o}}\right),
\end{aligned}
$$

where $x_{i}, x_{r}$, and $x_{o}$ are given, respectively, by [27]

$$
x_{i}=\left(\frac{v_{i}}{c}\right)^{k}, \quad x_{r}=\left(\frac{v_{r}}{c}\right)^{k}, \quad x_{o}=\left(\frac{v_{o}}{c}\right)^{k} .
$$

The capacity factor $C_{F}$ is a very important index of wind turbine productivity and represents the fraction of the output energy by the wind turbine over period of time to the energy which can be generated at the rated power. $C_{F}$ can be calculated by [27]

$$
C_{F}=\frac{E_{\text {out }}}{E_{r}}=\frac{E_{\text {out }}}{P_{r} T} .
$$

\section{Wind Data Analysis}

In this study, the measured wind speed data at $40 \mathrm{~m}$ for the period of January 2008 to December 2009 are analyzed. Using (4)-(5), the wind data at $40 \mathrm{~m}$ height are extrapolated to the $70 \mathrm{~m}$ height. Figure 3 shows monthly and annual mean wind speed at two heights of 40 and $70 \mathrm{~m}$. Clearly, wind speed at Jarandagh site follows constant pattern such that wind speed increases from January till July and August and then decreases till December. The maximum and minimum wind speed occur in January and December. At $40 \mathrm{~m}$ and $70 \mathrm{~m}$ heights, the wind speeds values are in the range of 5.87$11.25 \mathrm{~m} / \mathrm{s}$ and $6.69-12.45 \mathrm{~m} / \mathrm{s}$, respectively. In addition, the calculation results show that annual wind speed at heights

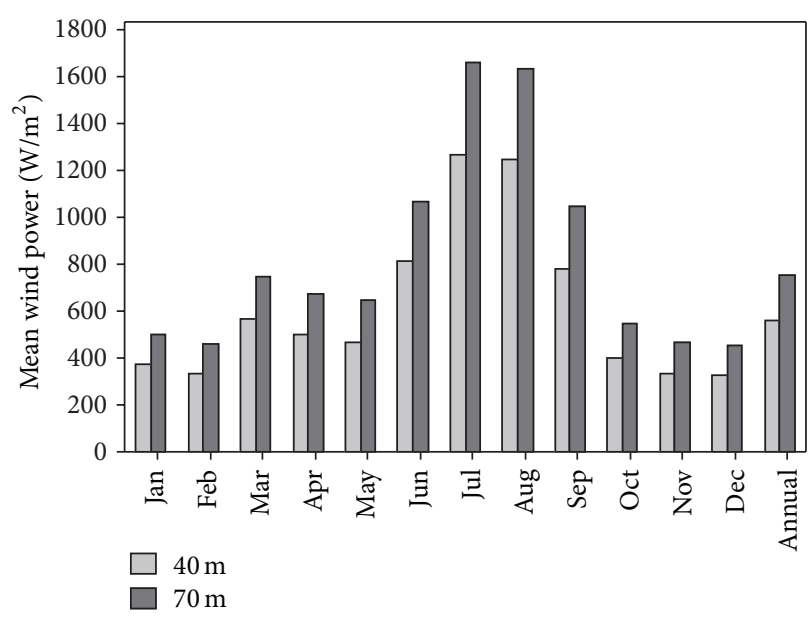

FIGURE 4: Monthly and annual mean wind power $\left(\mathrm{W} / \mathrm{m}^{2}\right)$ at 40 and 70 heights.

of $40 \mathrm{~m}$ and $70 \mathrm{~m}$ are $7.74 \mathrm{~m} / \mathrm{s}$ and $8.73 \mathrm{~m} / \mathrm{s}$, respectively. The monthly and annual mean wind power at $40 \mathrm{~m}$ and $70 \mathrm{~m}$ heights are illustrated in Figure 4. It is noticed that the wind power does not follow similar pattern with respect to wind speed throughout the year. The reason is due to higher standard deviation of wind speed in some months which results in higher values of wind power even with lower wind speed. The maximum and minimum wind power happen in July and December, respectively. Due to high variation of wind power in different months, it can be concluded that, in case of wind turbines installation in Jarandagh region, the energy output from systems would be subjected to significant differences throughout the year. However, the results specify that, at $40 \mathrm{~m}$ and $70 \mathrm{~m}$ heights, the wind power vary from 324.70 to $1267.06 \mathrm{~W} / \mathrm{m}^{2}$ and from 450.28 to $1661.62 \mathrm{~W} / \mathrm{m}^{2}$, respectively. Also, the annual wind power is 557.43 and $754.40 \mathrm{~W} / \mathrm{m}^{2}$, respectively. The Battelle-Pacific Northwest Laboratory (PNL) proposed a wind power classification for three heights of 10,30 , and $50 \mathrm{~m}$ to categorize the wind resource into 7 classes [28]. By interpolation of PNL wind power classification at $30 \mathrm{~m}$ and $50 \mathrm{~m}$, it is achieved that at $40 \mathrm{~m}$ height the wind power in 8 months from March to September falls into classes 5 to 7 which shows excellent potential of wind resource for wind farm construction [29]. In the remaining months Jarandagh wind resource falls into classes 3 and 4 which means moderate and good potential for wind energy harnessing [29]. However, the better conclusion can be obtained in terms of annual analysis which demonstrates that Jarandagh wind resource ranked in class 6 and consequently the region enjoys excellent potential for utilizing wind turbines.

The monthly and annual shape and scale parameters at 40 and $70 \mathrm{~m}$ heights are listed in Table 1 . It is observed that maximum and minimum Weibull parameters are obtained in July and January, respectively. At $40 \mathrm{~m}$ and $70 \mathrm{~m}$ heights, the annual shape parameters are 1.95 and 2.06, while the annual scale parameters are $8.83 \mathrm{~m} / \mathrm{s}$ and $9.85 \mathrm{~m} / \mathrm{s}$, respectively. 
TABLE 1: Monthly and annual shape and scale parameters at heights of 40 and $70 \mathrm{~m}$.

\begin{tabular}{lcccc}
\hline & $k(-) 40 \mathrm{~m}$ & $c(\mathrm{~m} / \mathrm{s}) 40 \mathrm{~m}$ & $k(-) 70 \mathrm{~m}$ & $c(\mathrm{~m} / \mathrm{s}) 70 \mathrm{~m}$ \\
\hline Jan & 1.41 & 6.45 & 1.49 & 7.41 \\
Feb & 1.64 & 6.82 & 1.73 & 7.82 \\
Mar & 1.51 & 7.74 & 1.60 & 8.80 \\
Apr & 1.77 & 8.10 & 1.88 & 9.18 \\
May & 2.17 & 8.54 & 2.30 & 9.65 \\
Jun & 1.78 & 9.54 & 1.89 & 10.72 \\
Jul & 2.83 & 12.63 & 2.99 & 13.94 \\
Aug & 2.69 & 12.44 & 2.85 & 13.75 \\
Sep & 2.26 & 10.24 & 2.39 & 11.45 \\
Oct & 1.83 & 7.62 & 1.94 & 8.67 \\
Nov & 1.77 & 7.09 & 1.88 & 8.10 \\
Dec & 1.72 & 6.92 & 1.82 & 7.92 \\
Annual & 1.95 & 8.73 & 2.06 & 9.85 \\
\hline
\end{tabular}

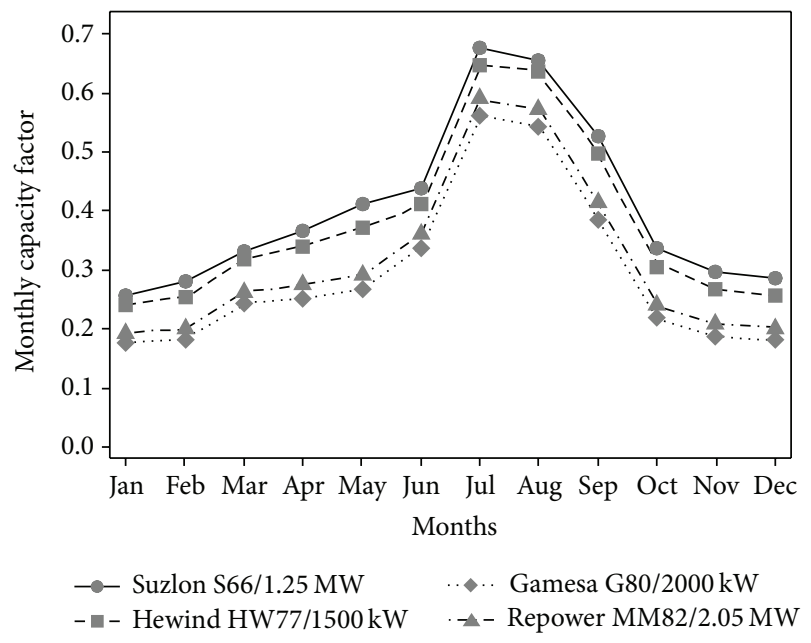

FIGURE 5: Monthly capacity factor for selected wind turbines at Jarandagh site.

\section{Performance Assessment of Nominated Wind Turbines}

For the wind turbines performance evaluation and finding the amount of energy that could be harnessed from wind turbines in Jarandagh area, four large-scale wind turbines (Suzlon S66/1.25 MW, Hewind HW77/1500 KW, Gamesa G80/2000 KW, and Repower MM82/2.05 MW) with different rated powers are nominated. The main technical information of nominated wind turbines are summarized in Table 2. These turbines were chosen from an inventory of available wind turbines in the market. The selected wind turbines are considered for operation at one of their standard hub heights equal to $70 \mathrm{~m}$.

The monthly capacity factors calculated for four wind turbines nominated in this study are presented in Figure 5. Capacity factor is function of the characteristic speed of the wind turbine (i.e., cut-in speed, rated speed, and cutout speed) as well as the wind regime characteristic of

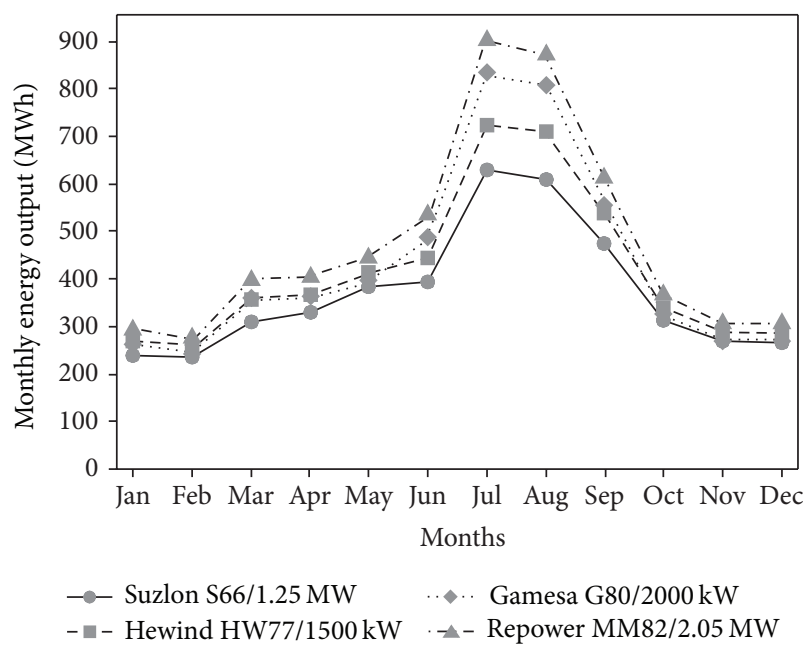

FIGURE 6: Total monthly energy output from selected wind turbines at Jarandagh site.

the location. Among characteristic speed of wind turbines, the rated wind speed has a significant influence on the amount of capacity factor [27]. According to Figure 5, capacity factor values vary significantly from each month to another also from each turbine to another. For all selected wind turbines the maximum and minimum values are achieved in June and January, respectively. It is noticed that the Suzlon S66/1.25 MW turbine model has the highest capacity factor whose values vary between 0.257 and 0.676 , while Gamesa G80/2000 kW model has the lowest capacity factors in the range of 0.176 and 0.560 . The main reason for difference between capacity factors from each turbine to another, as mentioned before, is due to the influence of rated wind speed on the amount of capacity factor. Total amount of energy output from each wind turbine in different months is illustrated in Figure 6. Despite the superior performance of Suzlon S66/1.25 MW turbine model in terms of capacity factor, the Repower MM82/2.05 MW model, because of higher rated power, produces the highest amount of electricity in all months, whereas the Suzlon S66/ 1.25 MW wind turbine model generates lowest amount of electricity. The total monthly energy output from the Suzlon S66/1.25 MW and the Repower MM82/2.05 MW models is the range of 238.94-628.89 MWh and 293.39-901.22 MWh, respectively.

The annual capacity factor and total annual of energy output for nominated wind turbines are shown in Figures 7 and 8 , respectively. The annual capacity factor of selected wind turbines falls within the very satisfactory range of $0.29-0.40$. However, similar to the monthly analysis, the lowest and highest capacity factors belong to the Gamesa G80/2000 kW and Suzlon S66/1.25 MW models, respectively. From Figure 8 , the lowest and highest total annual energy output are achieved using Suzlon S66/1.25 MW and Repower MM82/ 2.05 MW models equal to $4441 \mathrm{MWh}$ and $5705 \mathrm{MWh}$, respectively. At present, annual average of electricity consumption for each Iranian family is approximately $2500 \mathrm{kWh}$ [30]. Consequently, it seems that each wind turbine can be used 
TABLE 2: Technical data of nominated wind turbines [19-22].

\begin{tabular}{|c|c|c|c|c|c|c|c|}
\hline Wind turbine model & $\begin{array}{c}\text { Rated power } \\
(\mathrm{KW})\end{array}$ & $\begin{array}{c}\text { Cut-in speed } \\
(\mathrm{m} / \mathrm{s})\end{array}$ & $\begin{array}{c}\text { Rated speed } \\
(\mathrm{m} / \mathrm{s})\end{array}$ & $\begin{array}{c}\text { Cut-out } \\
\text { speed }(\mathrm{m} / \mathrm{s})\end{array}$ & $\begin{array}{l}\text { Hub height } \\
(\mathrm{m})\end{array}$ & $\begin{array}{c}\text { Rotor } \\
\text { diameter }(\mathrm{m})\end{array}$ & $\begin{array}{c}\text { Swept area } \\
\left(\mathrm{m}^{2}\right)\end{array}$ \\
\hline Suzlon S66/1.25 MW & 1250 & 4 & 12 & 20 & 72 & 66 & 3421 \\
\hline $\begin{array}{l}\text { Hewind } \\
\text { HW77/1500 KW }\end{array}$ & 1500 & 3 & 13 & 25 & $61.4,70,80$ & 77 & 4654 \\
\hline $\begin{array}{l}\text { Gamesa } \\
\text { G80/2000 KW }\end{array}$ & 2000 & 4 & 15 & 25 & $60-100$ & 80 & 5027 \\
\hline $\begin{array}{l}\text { Repower } \\
\text { MM82/2.05 MW }\end{array}$ & 2050 & 3.5 & 14.5 & 25 & $59-90$ & 82 & 5281 \\
\hline
\end{tabular}

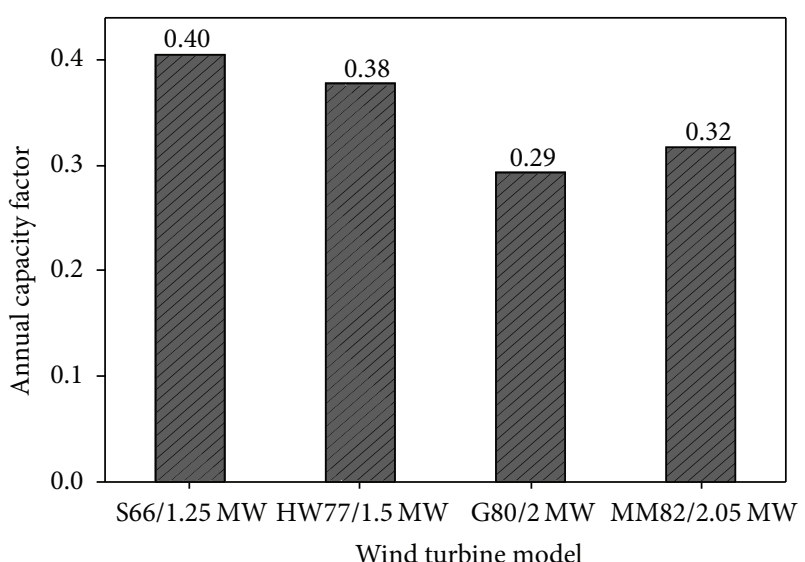

FIGURE 7: Annual capacity factor for nominated wind turbines at Jarandagh site.

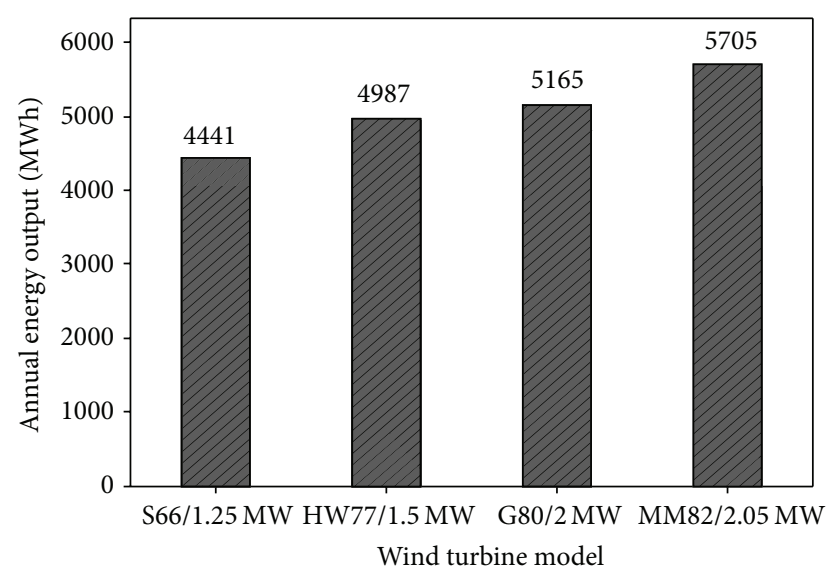

FIgURE 8: Total annual energy output from nominated wind turbines at Jarandagh site.

effectively to meet the electricity demand for several homes as well as other applications in the Jarandagh region and neighboring.

\section{Energy Cost Estimation}

Economic feasibility of wind turbine projects is usually relevant to the cost of energy generated by wind turbines. In this regard, the project should be optimized for the lowest possible cost per kWh energy generation. The cost of energy produced by wind turbines is function of many factors like wind speed, tax, installation, operation, and maintenance. With exception of wind turbine cost, others are location dependent [31]. The cost of wind turbines may vary according to the manufactures. However, the average specific cost of wind turbines for rated power of more than $200 \mathrm{~kW}$ can be taken as $1150 \$ / \mathrm{kW}$ [31]. In this study, the estimation of energy cost produced by wind turbines is conducted by calculating the energy cost per kilowatt hour $(C)$ which is the ratio of the accumulated present value of all costs (PVC) to the total energy generated by wind turbines during their lifetime $(n)$ [27].

The accumulated present value of all costs (PVC) including total initial investment cost of the wind turbine installation project $\left(C_{I}\right)$ is [27]

$$
\mathrm{PVC}=C_{I}\left\{1+m\left[\frac{(1+I)^{n}-1}{I(1+I)^{n}}\right]\right\},
$$

where $m$ is the annual operation and maintenance cost and $I$ is the real discount rate.

The output energy $\left(E_{\text {out }}\right)$ produced by the wind turbine in one year, according to (10), is [27]

$$
E_{\text {out }}=8760 P_{r} C_{F} \text {, }
$$

where $P_{r}$ and $C_{F}$ are rated power and capacity factor of the turbine.

Therefore, cost of electricity generated by wind turbine in terms of money/kWh can be calculated by [27]

$$
C=\frac{\mathrm{PWC}}{E_{\mathrm{out}}}=\frac{C_{I}}{8760 n}\left(\frac{1}{P_{r} C_{F}}\right)\left\{1+m\left[\frac{(1+I)^{n}-1}{I(1+I)^{n}}\right]\right\} .
$$

The following assumptions are considered in this study for economic evaluation [27].

(1) The other initial costs including installation, transportation, custom fee, and grid integration are assumed $40 \%$ of the turbine cost. Installation period is neglected.

(2) The real discount rate, $I$, can approximately be taken as the difference between interest rate and inflation rate. Interest rate and inflation rate are considered $20 \%$ and $16 \%$, respectively. So, the real discount rate is equal to $4 \%$. 


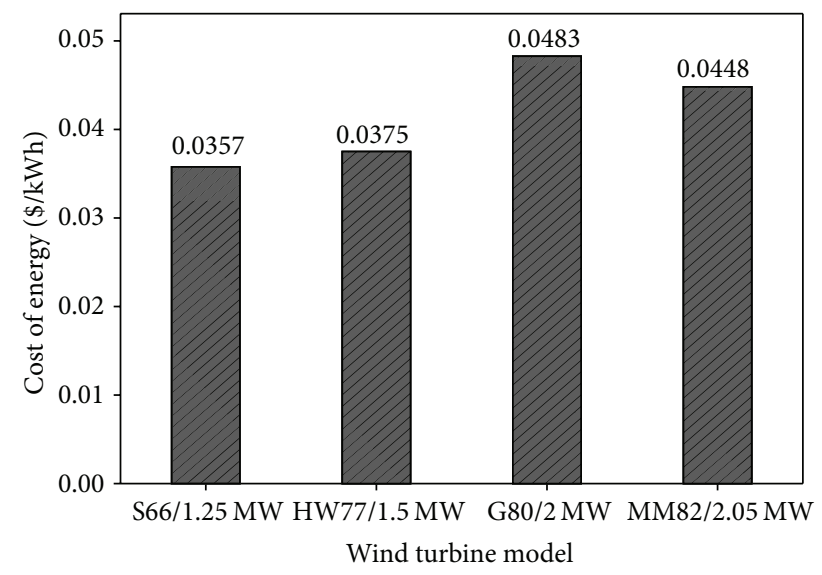

Figure 9: Cost of energy $(C)$ produced by selected wind turbines in terms of $\$ / \mathrm{kWh}$.

(3) Annual operation and maintenance costs plus the land rent, $m$, are taken to be $4 \%$ of the turbine cost.

(4) Expected useful life, $n$, of the turbines is 20 years.

Figure 9 shows the results of the energy cost per kWh for selected wind turbines. Currently, the purchase tariff for electricity produced by renewable energy sources adapted by Iranian government is $0.13 \$ / \mathrm{kWh}$ [32]. Noticeably, the cost of energy produced by all nominated wind turbines at Jarandagh site is much lower than approved purchase tariff; hence, any investment by national and international private markets for construction of wind farms in Jarandagh region seems very profitable. According to Figure 9, the lowest energy cost is achieved using Suzlon S66/1.25 MW turbine model equal to $0.0357 \$ / \mathrm{kWh}$, while the highest energy cost is obtained with Gamesa G80/2000 kW model equal to $0.0483 \$ / \mathrm{kWh}$. Thus, according to the energy cost estimation results, the Suzlon S66/1.25 MW wind turbine model is suggested as the most economical option for wind farms constructing in Jarandagh region.

\section{Conclusion}

In the current study, the possibility of electricity production using wind energy in Jarandagh located in north-west part of Iran was investigated. The wind energy potential was evaluated by analyzing the measured wind speed data between 2008 and 2009 at $40 \mathrm{~m}$ height. Besides, the performance and economic assessment of four large-scale wind turbine models for operation at $70 \mathrm{~m}$ height were studied. The following conclusions can be drawn from the results of this study.

(1) The results at $70 \mathrm{~m}$ height were achieved by extrapolating of wind data. It was found that, at the height of $70 \mathrm{~m}$, the mean wind speed values vary between 6.69 and $12.45 \mathrm{~m} / \mathrm{s}$ in different months of the year. The annual wind speed is $8.73 \mathrm{~m} / \mathrm{s}$. The monthly mean wind power ranges from 450.28 to $1661.62 \mathrm{~W} / \mathrm{m}^{2}$, respectively. Also, the annual mean wind power is $754.40 \mathrm{~W} / \mathrm{m}^{2}$, respectively.
(2) The analysis results illustrated that in 8 months from March to September Jarandagh enjoys excellent wind energy potential for wind farm construction whose wind power falls in classes 5 to 7 , while in the remaining months Jarandagh wind resource falls into classes 3 and 4 that means moderate and good potential for wind energy harnessing. Besides, in terms of annual analysis it was observed that Jarandagh wind resource ranked in class 6; therefore, the region enjoys excellent potential for utilizing wind turbines.

(3) The highest and lowest capacity factor were obtained using Suzlon S66/1.25 MW and Gamesa G80/ $2000 \mathrm{~kW}$ wind turbine models with annual values of 0.4 and 0.29 , respectively. In terms of electricity generation, the maximum and minimum energy output were found for Repower MM82/2.05 MW and Suzlon S66/1.25 MW models which can generate $4441 \mathrm{MWh}$ and $5705 \mathrm{MWh}$ electricity in the whole year, respectively.

(4) The obtained results for energy cost estimation showed that the cost of energy produced by all nominated wind turbines at Jarandagh site is much lower than current renewable energy purchase tariff in Iran $(0.13 \$ / \mathrm{kWh})$; hence, any investment by private markets for wind farms construction in Jarandagh region seems very profitable. Furthermore, the least energy cost is achieved using Suzlon S66/1.25 MW turbine model equal to $0.0357 \$ / \mathrm{kWh}$.

The study result highly encourages the construction of wind farms in Jarandagh for the purpose of electricity generation which provide a sustainable energy base for the region. In addition, the S66/1.25 MW wind turbine model is recommended as the most attractive option.

\section{Conflict of Interests}

The authors declare that there is no conflict if interests regarding the publication of this paper.

\section{References}

[1] M. J. Shawon, L. El Chaar, and L. A. Lamont, "Overview of wind energy and its cost in the Middle East," Sustainable Energy Technologies and Assessments, vol. 2, no. 1, pp. 1-11, 2013.

[2] A. Mostafaeipour, A. Sedaghat, A. A. Dehghan-Niri, and V. Kalantar, "Wind energy feasibility study for city of Shahrbabak in Iran," Renewable and Sustainable Energy Reviews, vol. 15, no. 6, pp. 2545-2556, 2011.

[3] A. Miketa and P. Mulder, "Energy productivity across developed and developing countries in 10 manufacturing sectors: patterns of growth and convergence," Energy Economics, vol. 27, no. 3, pp. 429-453, 2005.

[4] November 2013, http://www.suna.org/.

[5] J. F. Manwell, J. G. McGowan, and A. L. Rogers, Wind Energy Explained-Theory, Designand Application, John Wiley \& Sons, New York, NY, USA, 2002.

[6] M. Hoogwijk, B. de Vries, and W. Turkenburg, "Assessment of the global and regional geographical, technical and economic 
potential of onshore wind energy," Energy Economics, vol. 26, no. 5, pp. 889-919, 2004.

[7] M. Abbes and J. Belhadj, "Wind resource estimation and wind park design in El-Kef region, Tunisia," Energy, vol. 40, no. 1, pp. 348-357, 2012.

[8] K. Mohammadi and A. Mostafaeipour, "Using different methods for comprehensive study of wind turbine utilization in Zarrineh, Iran," Energy Conversion and Management, vol. 65, pp. 463-470, 2013.

[9] A. Akpinar, "Evaluation of wind energy potentiality at coastal locations along the north eastern coasts of Turkey," Energy, vol. 50, no. 1, pp. 395-405, 2013.

[10] A. Keyhani, M. Ghasemi-Varnamkhasti, M. Khanali, and R. Abbaszadeh, "An assessment of wind energy potential as a power generation source in the capital of Iran, Tehran," Energy, vol. 35, no. 1, pp. 188-201, 2010.

[11] M. R. Islam, R. Saidur, and N. A. Rahim, "Assessment of wind energy potentiality at Kudat and Labuan, Malaysia using Weibull distribution function," Energy, vol. 36, no. 2, pp. 985992, 2011.

[12] M. Mirhosseini, F. Sharifi, and A. Sedaghat, "Assessing the wind energy potential locations in province of Semnan in Iran," Renewable and Sustainable Energy Reviews, vol. 15, no. 1, pp. 449-459, 2011.

[13] A. Mostafaeipour and H. Abarghooei, "Harnessing wind energy at Manjil area located in north of Iran," Renewable \& Sustainable Energy Reviews, vol. 12, no. 6, pp. 1758-1766, 2008.

[14] D. Saeidi, M. Mirhosseini, A. Sedaghat, and A. Mostafaeipour, "Feasibility study of wind energy potential in two provinces of Iran: North and South Khorasan," Renewable and Sustainable Energy Reviews, vol. 15, no. 8, pp. 3558-3569, 2011.

[15] A. Mostafaeipour, A. Sedaghat, M. Ghalishooyan et al., "Evaluation of wind energy potential as a power generation source for electricity production in Binalood, Iran," Renewable Energy, vol. 52, pp. 222-229, 2013.

[16] K. Mohammadi and A. Mostafaeipour, "Economic feasibility of developing wind turbines in Aligoodarz, Iran," Energy Conversion and Management, vol. 76, pp. 645-653, 2013.

[17] A. Mostafaeipour, M. Jadidi, K. Mohammadi, and A. Sedaghat, "An analysis of wind energy potential and economic evaluation in Zahedan, Iran," Renewable and Sustainable Energy Reviews, vol. 30, pp. 641-650, 2014.

[18] http://www.wikipedia.com.

[19] June 2013, http://www.suzlon.com.

[20] http://www.hewind.com/.

[21] http://www.gamesacorp.com/.

[22] June 2013, http://www.repower.com/.

[23] C. G. Justus, W. R. Hargraves, A. Mikhail, and D. Graber, "Methods for estimating wind speed frequency distributions," Journal of Applied Meteorology, vol. 17, no. 3, pp. 350-353, 1978.

[24] A. N. Celik, "Weibull representative compressed wind speed data for energy and performance calculations of wind energy systems," Energy Conversion and Management, vol. 44, no. 19, pp. 3057-3072, 2003.

[25] E. K. Akpinar and S. Akpinar, "An assessment on seasonal analysis of wind energy characteristics and wind turbine characteristics," Energy Conversion and Management, vol. 46, no. 11-12, pp. 1848-1867, 2005.

[26] B. Safari and J. Gasore, "A statistical investigation of wind characteristics and wind energy potential based on the Weibull and Rayleigh models in Rwanda," Renewable Energy, vol. 35, no. 12, pp. 2874-2880, 2010.

[27] S. Mathew, Wind Energy: Fundamentals, Resource Analysis and Economics, Springer, Berlin, Germany, 2006.

[28] D. L. Elliott and M. N. Schwartz, "Wind energy potential in the United States," NTIS no. DE94001667, PNL-SA-23109, Pacific Northwest Laboratory, Richland, Wash, USA, 1993.

[29] X. Yu and H. Qu, "Wind power in China: opportunity goes with challenge," Renewable and Sustainable Energy Reviews, vol. 14, no. 8, pp. 2232-2237, 2010.

[30] http://www.irna.ir/fa/News.

[31] M. S. Adaramola, S. S. Paul, and S. O. Oyedepo, "Assessment of electricity generation and energy cost of wind energy conversion systems in North-central Nigeria," Energy Conversion and Management, vol. 52, no. 12, pp. 3363-3368, 2011.

[32] http://www.mojnews.com/en/Miscellaneous/ViewContents .aspx?...I. 


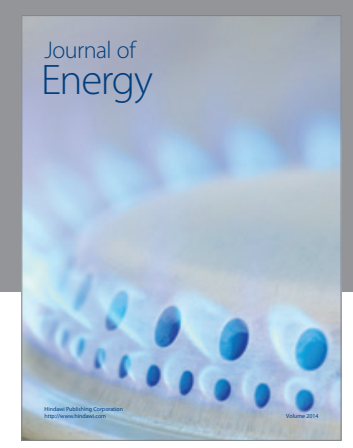

Journal of

Industrial Engineering
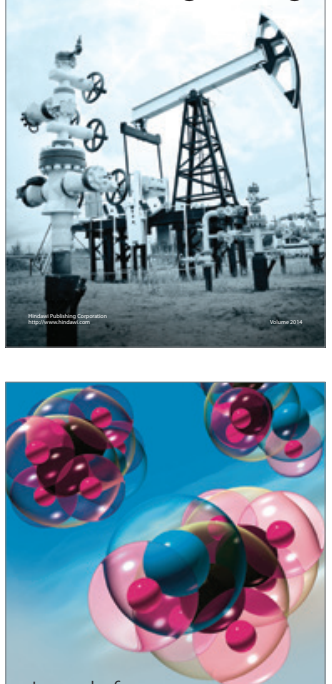

Fuels
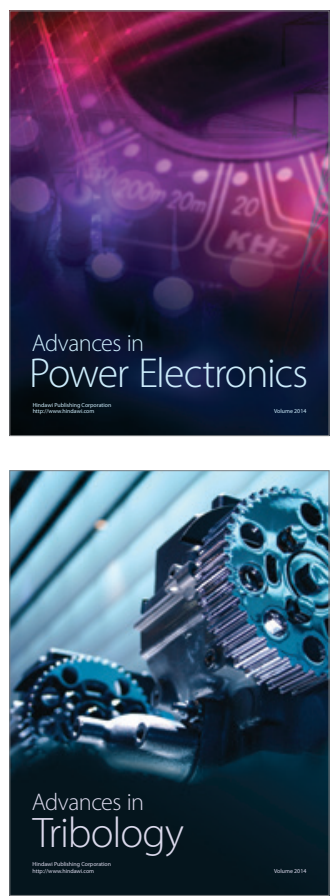

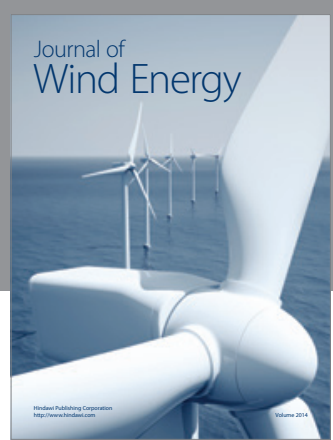

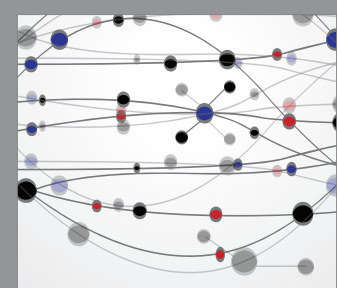

The Scientific World Journal

Submit your manuscripts at http://www.hindawi.com

Journal of

Structures
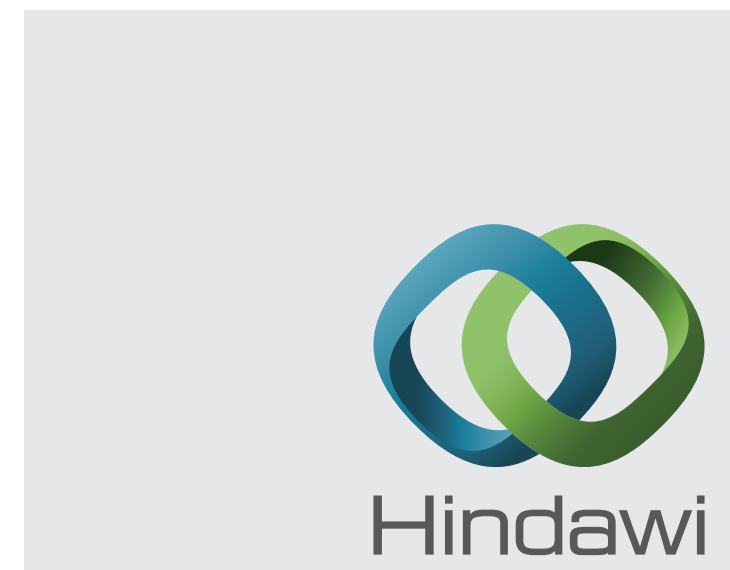

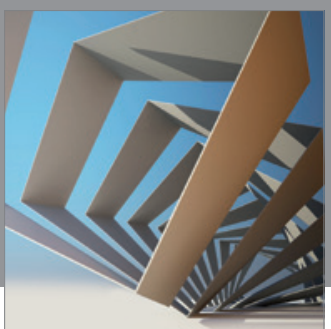

Rotating

Machinery
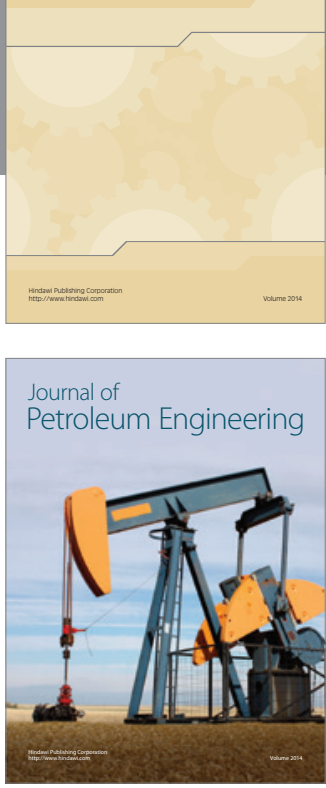

Journal of

Solar Energy
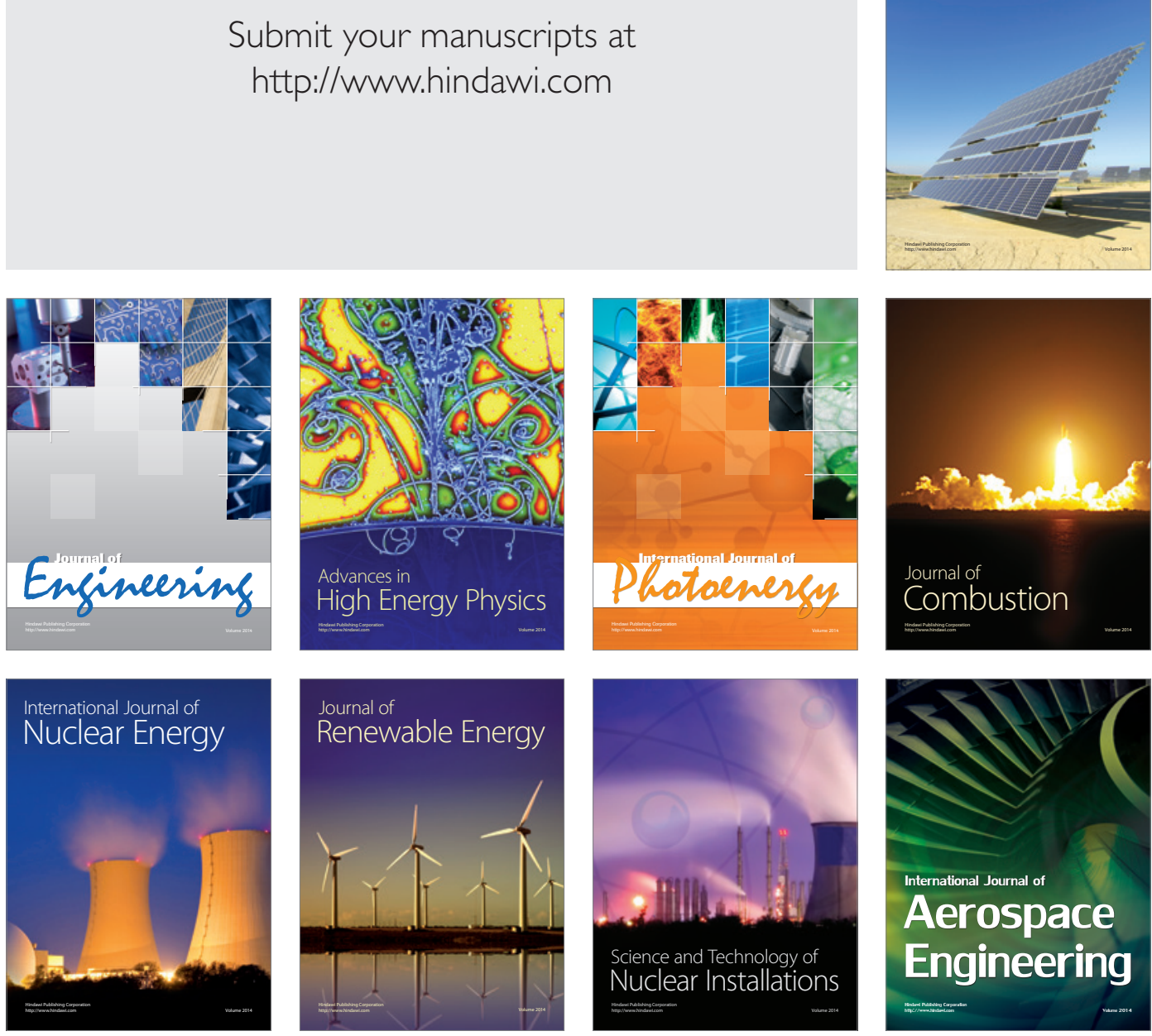